\title{
Full Scale Measurements and CFD Simulations of Diffuse Ceiling Inlet for Ventilation and Cooling of Densely Occupied Rooms
}

\author{
Mikeska, Tomás; Fan, Jianhua
}

Published in:

Energy and Buildings

Link to article, DOI:

10.1016/j.enbuild.2015.06.070

Publication date:

2015

Document Version

Early version, also known as pre-print

Link back to DTU Orbit

Citation (APA):

Mikeska, T., \& Fan, J. (2015). Full Scale Measurements and CFD Simulations of Diffuse Ceiling Inlet for Ventilation and Cooling of Densely Occupied Rooms. Energy and Buildings, 107, 59-67.

https://doi.org/10.1016/i.enbuild.2015.06.070

\section{General rights}

Copyright and moral rights for the publications made accessible in the public portal are retained by the authors and/or other copyright owners and it is a condition of accessing publications that users recognise and abide by the legal requirements associated with these rights.

- Users may download and print one copy of any publication from the public portal for the purpose of private study or research.

- You may not further distribute the material or use it for any profit-making activity or commercial gain

- You may freely distribute the URL identifying the publication in the public portal 


\title{
Full Scale Measurements and CFD Simulations of Diffuse Ceiling Inlet for Ventilation and Cooling of Densely Occupied Rooms
}

\author{
Tomas Mikeska*, Jianhua Fan \\ Department of Civil Engineering, Technical University of Denmark, Brovej, Building 118, DK-2800 Kgs. Lyngby, \\ Denmark
}

\begin{abstract}
Spaces with high occupant densities result in high heat gains and need for relatively high air change rate. By means of traditional mechanical ventilation diffusers it becomes a challenge to supply large amounts of fresh air into the space without creating a local discomfort for occupants. One solution to this problem is use of a diffuse ceiling inlet supplying a fresh air into the room through a large area of perforated ceiling.

The aim of this paper was to report the research conducted on diffuse ceiling inlet installed in the full scale test outdoor facility. The diffuse ceiling inlet based on gypsum boards with airtight connections was created utilizing the full potential of diffuse layer without undesirable crack flow reported by other authors. The measured values were used to validate the detailed Large Eddy Simulation model of test room created in CFD software with aim to evaluate an indoor comfort numerically.

Results of our investigations have shown that diffuse ceiling inlet is a suitable solution for the spaces with high density occupancy. The results have shown that transient calculations using Large Eddy Simulation models can predict well temperatures and velocity magnitude of air flow in the room.
\end{abstract}

*Corresponding author: Tel.: +4527338619, E-mail: tommi@byg.dtu.dk 


\section{Keywords}

Diffuse ceiling inlet

Large Eddy Simulation

Computational Fluid Dynamics

Indoor climate

Classroom

\section{Nomenclature}

CFD Computational Fluid Dynamics

EU European Union

PMV Predicted mean vote

PPD Predicted percentage of dissatisfied

USA United States of America 


\section{Introduction}

The use of mechanical ventilation in buildings occupied by humans is getting more importance nowadays, since it is no longer possible to meet energy requirements with use of natural ventilation. The energy use in new buildings must be reduced in all countries within EU to the level of nearly zero energy building [1]. The requirements of EU are understandable, taking into account that about $40 \%$ of overall consumption of energy within EU is in building sector [1]. Similar situation is in the USA. On worldwide scale, the fraction of energy used for buildings is about $24 \%$ [2]. The use of mechanical ventilation with a heat recovery can save up to $90 \%$ of energy, otherwise used for ventilation of buildings. Such savings are unrealistic with use of natural ventilation.

Due to the wrong choice of ventilation system and poor overall design, schools have generally very poor indoor climate [3]. Similar findings were obtained from investigations in buildings with different purposes which were poorly ventilated, such as offices, call centers etc. [4]. Wyon in his experiment found that poor indoor climate can result in decrease of performance up to $9 \%$ [5]. Wargocki and Wyon observed increased performance among students when outdoor air supply was increased from $4 \mathrm{l} / \mathrm{s} \cdot$ person to $10 \mathrm{l} / \mathrm{s} \cdot$ person [6]. Authors also claim that the performance of children in schools can be increased by up to $30 \%$ compared to the situation in average educational institution.

Traditional mixing and displacement inlet diffusers are usually used for most of the installations in buildings occupied by humans. However, there are situations where traditional types of diffusers are not able to deliver required amount of conditioned air in comfortable ways, are not able to remove large heat gains and are not able to comply with relevant standards concerning indoor climate. Spaces difficult to ventilate with traditional types of diffusers include educational rooms, meeting rooms, conference centers, theaters etc. Diffuse ceiling inlet seems to be a better alternative to traditional diffusers for mentioned spaces.

Diffuse ceiling inlet ventilation is characterized by activation of large area of ceiling as an inlet device. The fresh air is supplied into the space at very low velocity. The large air volumes can be supplied to the space without having a risk of creating any draughts. In principle, the fresh outside air is supplied into the space between the ceiling slab and perforated suspended ceiling, so-called plenum, where it gets uniformly distributed. Then the air comes into the room through perforated gypsum boards. The over-pressure is kept in the plenum thanks to a sound absorbing material (an acoustic textile) being installed on top of the perforated gypsum boards. This solution creates a pressure chamber, allowing the supply air to be distributed equally through the whole area of the perforated suspended ceiling. This 
results in a whole surface acting as a supply air terminal device. Perforated suspended ceiling can be created from different types of materials (other than gypsum). As an example, Hviid used aluminum tiles in one work [7] and shredded spruce wood mixed with wool and cement in other study [8].

Diffuse ceiling inlet is nowadays mainly known in livestock industry where it was previously used as a supply diffuser in agricultural buildings $[7,9]$. Some of the applications were also done in public buildings, mainly during renovation of classrooms [10]. Other example of installation of diffuse ceiling inlet is administrative building for headquarter of large company [11]. Some previous investigations have been done in real buildings. Hviid studied performance of diffuse ceiling inlet in classroom [8]. He found that good level of mixing was reached in the room. The uniform temperature and airflow distribution was experienced, without any risk of draught. Jensen studied the cooling benefits of diffuse ceiling inlet. Reduced hours of overheating in the room were reported [10]. Other investigations took place in experimental facilities. Nielsen focused in his study on performance of diffusive ceiling ventilation in office space with two manikins and basic office equipment [12]. The results have shown that diffuse ceiling inlet was able to handle higher thermal loads and higher flow rates compare to five other ventilation systems. Hviid in his experiment realized that suspension construction had great influence on the air flow to the room [7]. He found out that more air was coming from the plenum to the room through the attachment of perforated tiles with suspension construction, instead of going directly through the perforation of the tiles.

To the best knowledge of authors, no work has been so far done on diffuse ceiling inlet based on acoustic ceiling gypsum boards with absolutely airtight connections distributing the supply air equally over the whole area of suspended ceiling. The aim of this paper is to report the research conducted on diffuse ceiling inlet based on acoustic ceiling gypsum boards with airtight connections, hence utilize the full potential of diffuse layer without undesirable crack flow reported by Hviid [7]. Such a solution creates a basis for validation of a CFD model using a porous zone to simulate the diffuse ceiling inlet. The thorough CFD calculations are done with use of Large Eddy Simulation equations in order to reliably model the effect of turbulence fluctuations on the air flow in the room. The reduced area of supply diffuser is investigated with aim to improve the mixing of supply air with room air and also to improve air distribution in the room. Diffuse ceiling inlet cools the room down by use of outside air without creating any draught problems and with use of relatively small amount of energy to run the fans as pressure drop over the suspended ceiling is rather 
small. A densely occupied classroom situated in the real test building equipped with de-centralized ventilation unit is investigated.

\section{Materials and methods}

\subsection{Experimental measurements}

The following chapters describe the materials and methods which have been used during our investigation.

\subsubsection{Full scale testing facility}

The experimental part of this research was carried out in the full scale test building, which was built from sandwich elements made of high performance concrete. It is two storeys building, where upper floor was used for purposes of this paper. The outer layer of high performance concrete had $20 \mathrm{~mm}$, inner layer of high performance concrete had 30 $\mathrm{mm}$ and thermal insulation was $300 \mathrm{~mm}$ thick. The planar inside dimensions of the test room were $6.05 \mathrm{~m} \times 3.25 \mathrm{~m}$, resulting in an area of $19.66 \mathrm{~m}^{2}$, (Figure 1). The height of the test room after installation of suspended ceiling was 2.65 $\mathrm{m}$. Two windows with three-layer glass and dimensions $2.50 \mathrm{~m} \times 1.10 \mathrm{~m}$ were installed in the north-western facade. The resulting area of windows was $5.50 \mathrm{~m}^{2}$. The partition wall separated the room from an entrance space which also served as a small technical room (Figure 1). Its purpose was purely to divide the two spaces in terms of air flow. The partition wall was made of wood and gypsum boards. Floor and ceiling decks were made of hollow core concrete elements with a thickness of $0.2 \mathrm{~m}$.

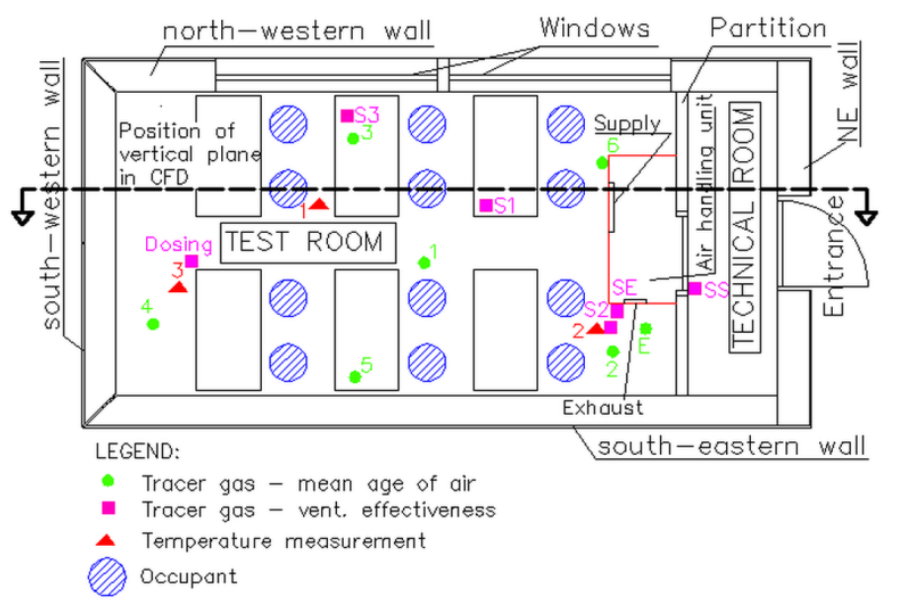

Figure 1: Layout of test room and positions of measuring points 


\subsubsection{Diffuse ceiling inlet construction}

Diffuse ceiling inlet was created from perforated gypsum boards with dimensions $0.9 \mathrm{~m} \times 2.7 \mathrm{~m}$ and total perforated area of $15.5 \%$. Connections between boards and slots around any penetrating objects were sealed by silicone paste. The plenum was built $0.28 \mathrm{~m}$ high in order to separate the inlet and exhaust of the air handling unit by the perforated suspended ceiling construction. Resulting height of the room after installation of perforated suspended ceiling was $2.65 \mathrm{~m}$. The surface area of perforated suspended ceiling is decreased by obstructing ventilation unit resulting in an area of $18.6 \mathrm{~m}^{2}$. The volume of the investigated room (excluding plenum) was then $52.9 \mathrm{~m}^{3}$.

\subsubsection{Air handling unit}

The decentralized air handling unit was installed under the concrete ceiling deck being partially situated in the plenum and partly in the room (Figure 2). The fresh air was supplied from the air handling unit into the plenum through the grill with dimensions of $0.8 \mathrm{~m} \times 0.1 \mathrm{~m}$ situated on the front face of the unit, $0.05 \mathrm{~m}$ below the ceiling deck, oriented into the plenum. An uniform air distribution in the plenum was assumed, creating a chamber with equivalent static pressure drop. The exhaust opening with dimensions of $0.15 \mathrm{~m} \times 0.1 \mathrm{~m}$ was placed on a side of the unit and situated just below the perforated suspended ceiling in the room.

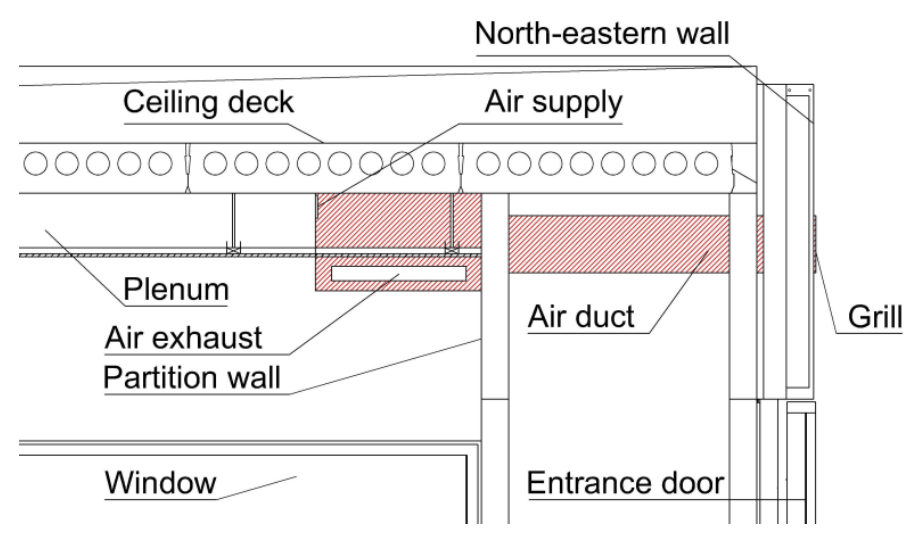

Figure 2: Position of air handling unit 


\subsubsection{Other appliances installed in the room}

Four lighting units with fluorescent tubes with power of $28 \mathrm{~W} /$ unit were installed, situated $0.2 \mathrm{~m}$ below the perforated suspended ceiling. The room was further equipped with 12 class room tables with dimensions of $1.2 \mathrm{~m} \times 0.7 \mathrm{~m}$ and 12 chairs. The occupants were simulated by manikins created from steel buckets and painted to black color so the generated heat is emitted from the body of manikin. The manikins had cylindrical shape with diameter of $0.35 \mathrm{~m}$ and height of $0.45 \mathrm{~m}$ and were placed at chairs.

\subsubsection{Investigated scenarios}

Our setup simulated a densely occupied classroom. Twelve manikins were seated in pairs behind the tables in three rows (Figure 1). The heat was generated by $75 \mathrm{~W}$ bulbs inside each manikin, which is an equivalent to a sensible heat production of a sedentary person. The assumption was that occupants have activity level of 1.0 met (seated, quiet) and clothing insulation equal to 0.8 clo (spring period). Latent heat gains generated by human respiration were neglected.

Two different scenarios were investigated with balanced supply and exhaust airflows of: 1) $350 \mathrm{~m}^{3} / \mathrm{h}$ and 2) $480 \mathrm{~m}^{3} / \mathrm{h}$, corresponding to the air change rate $6.6 \mathrm{~h}^{-1}$ and $9.1 \mathrm{~h}^{-1}$ respectively. The flow measurement was done by principle of a multi-port averaging pitot tube and resulting accuracy of flow measurements was $\pm 10 \%$ [13]. Chosen airflows complied with class B and A, respectively, required by a standard for classrooms [14]. The temperatures of outside air were $0.1{ }^{\circ} \mathrm{C}$ and $2.6^{\circ} \mathrm{C}$ for Scenario 1 and 2 respectively. The temperatures of air in the room situated below the test room were $24.2^{\circ} \mathrm{C}$ and $22.9^{\circ} \mathrm{C}$ for Scenario 1 and 2 respectively.

\subsubsection{Indoor climate evaluation}

Indoor climate is most often evaluated by air quality and thermal comfort. Thermal comfort criteria were assessed by means of Predicted Mean Vote (PMV) and Predicted Percentage of Dissatisfied (PPD) [15]. Furthermore, airflow behavior and ventilation effectiveness were assessed by means of tracer-gas measurements.

\subsubsection{Temperature measurements}

The T-type thermocouples were used to measure temperatures of air in the room and plenum and also of all surfaces. Temperatures were measured continuously for the entire period of experiment and recorded in a minute interval. 
12 pieces of T-type thermocouples were installed at different heights on three moveable stands situated within the occupied zone of the room, see Figure 1. Thermocouples were situated in aluminum cylinders in order to be shielded against the effects of thermal radiation. Thermocouples were fixed at height levels of $0.1 \mathrm{~m}, 0.6 \mathrm{~m}, 1.1 \mathrm{~m}$ and $1.7 \mathrm{~m}$, respectively, in order to be able to evaluate the vertical temperature profile, which was used as an indicator of local thermal comfort evaluation, as shown in [15]. The difference between heights $0.1 \mathrm{~m}$ and $1.7 \mathrm{~m}$ should not exceed $3 \mathrm{~K}$. Additional 12 thermocouples were installed to measure the surface temperatures of walls, 12 thermocouples were placed on the bottom side of the perforated suspended ceiling, 4 thermocouples were placed on the floor and 2 measured temperature of window surface. A total of 36 thermocouples were installed in the plenum. The precision of measurements with installed thermocouples was $0.3 \mathrm{~K}[16]$. The outside temperature was measured by use of $\mathrm{HOBO}$ loggers with precision of $0.35 \mathrm{~K}[17]$.

\subsubsection{Air velocity measurements}

Air velocities in the room were measured by use of air velocity transducers SensoAnemo5100SF [18]. Accuracy of used equipment was $1 \%$ for velocities below $5 \mathrm{~m} / \mathrm{s}$. Measurements were carried out in the occupied zone on positions of the vertical stands at heights $0.1 \mathrm{~m}, 0.6 \mathrm{~m}, 1.1 \mathrm{~m}$ and $1.7 \mathrm{~m}$ respectively. The measurements were taken after the room was stabilized. Draught rating index was used to describe the magnitude of draught and is defined as a percentage of people predicted to be bothered by draft. Draught rating is most common cause of local discomfort and it is recommended by ISO7730 to be kept below $15 \%$ [15]. Draught rating was calculated according to Eq. (1).

$$
D R=\left(34-t_{a}\right) \cdot(v-0.05)^{0,62}\left(0.37 \cdot v \cdot T_{u}+3.14\right)[\%] \quad \text { Eq. (1) }
$$

Where: $t_{a}$ is temperature of air at place of measurement $\left[{ }^{\circ} \mathrm{C}\right], v$ is mean air velocity at place of measurement [m/s], $T_{u}$ is turbulence intensity at place of measurement [\%].

Concerning general velocities in occupied zone, those should not exceed $0.16 \mathrm{~m} / \mathrm{s}$ in winter and $0.19 \mathrm{~m} / \mathrm{s}$ in summer period (for class B) [15]. The values could be possibly adjusted according to the activity and clothing level of the occupants.

\subsubsection{Tracer-gas measurements}

In order to find a pattern of air distribution in the room, the thorough investigations with use of tracer gas were performed. The multi-gas analyzers Innova [19] were used for those purposes. The tracer gas was dosed and sampled 
by a multipoint sampler and doser unit Innova 1303, and its concentration was measured by use of a photo acoustic multi gas monitor Innova 1312. Freon R134a $\left(C_{2} H_{2} F_{4}\right)$ was used as a tracer gas. The accuracy of dosage amount was $\pm 2 \%$

Ventilation effectiveness $\left(\varepsilon_{v}\right)$ was calculated, in order to evaluate a level of air mixing in the room. The tracer gas concentrations were measured in supply duct (S), exhaust duct (SE) and three different positions within the occupied zone $(\mathrm{S} 1, \mathrm{~S} 2, \mathrm{~S} 3)$, at height of $1.1 \mathrm{~m}$, see Figure 1. Freon was dosed in the room in distance of $2.5 \mathrm{~m}$ from closest sampling point. Eq. (2) was used to calculate the ventilation effectiveness for each investigated point in the room. Overall room ventilation effectiveness was then calculated as an average of the three measured points.

$$
\varepsilon_{v}=\frac{C_{e}-C_{s}}{C_{i}-C_{S}}[\%] \text { Eq. (2) }
$$

Where: $C_{e}$ is pollution concentration in the exhaust air [PPM]; $C_{s}$ is pollution concentration of the supplied air (background concentration) [PPM]; and $C_{i}$ is pollution concentration in the breathing zone [PPM].

Additionally, the Local Mean Age of air describing a time required for a supply air to reach a particular point in the occupied zone was measured. This was done in order to compare the performance of ventilation system in different positions of the room. Freon was supplied at a constant rate to the air handling unit where it was dispersed by the fan and supplied into the plenum and then to the room. Freon concentrations were measured at 6 points at height level of $1.1 \mathrm{~m}$ in the occupied zone (see Figure 1). Local Mean Age of air was obtained by integrating the area above concentration curve divided by steady state concentration, according to the step up method adapted from Han [20], see Eq. (3).

$$
\theta_{p}=\int_{o}^{\infty}\left(1-\frac{c_{p}(t)}{c_{p}(\infty)}\right) d t[s] \quad \text { Eq. (3) }
$$

Where: $c_{p}$ is measured concentration in point $P$ in equilibrium $[p p m]$.

\subsection{Numerical calculations}

The 3-dimensional numerical model was created in a Computational Fluid Dynamics (CFD) software tool in order to allow for further investigations of diffuse ceiling inlet performance, see Figure 3. The commercial CFD program Ansys Fluent 14.0 was used for numerical calculations [21]. 


\subsubsection{The grid creation}

The hexahedral grid with $4,354,482$ cells was created. The maximum skeweness of the model was 0.3 which is considered to be very good according to Nielsen [22]. Average value of skeweness was smaller than 0.00045 , and therefore the main precondition for having a successful correlation with experimental measurements was reached. The mesh was refined in areas close to the surfaces where rapid change in velocity or temperature can occur. The independence of the grid on results of CFD calculations was investigated by creating four grids with different cell counts and the results are shown in Table 1. The results of calculated temperatures and velocities for horizontal plane at height $1.1 \mathrm{~m}$ show only minor deviations. The calculated solutions are therefore grid independent.

Table 1: Grid independence investigations

\begin{tabular}{lccccc}
\hline & & Grid 1 & Grid 2 & Grid 3 & Grid 4 \\
Grid cells amount & {$[\mathrm{pcs}]$} & 645,432 & $1,030,544$ & $1,964,820$ & $4,354,482$ \\
\hline Average air temperature at 1.1 $\mathrm{m}$ & {$\left[{ }^{\circ} \mathrm{C}\right]$} & 24.2 & 24.1 & 24.2 & 24.3 \\
Average air temperature at exhaust & {$\left[{ }^{\circ} \mathrm{C}\right]$} & 24.5 & 24.6 & 24.6 & 24.6 \\
Average velocity at 1.1 $\mathrm{m}$ & {$[\mathrm{m} / \mathrm{s}]$} & 0.073 & 0.069 & 0.073 & 0.079 \\
\hline Heat flux imbalance & {$[\mathrm{W}]$} & 12.6 & 2.8 & 8.7 & 3.3 \\
Heat flux imbalance & {$[\%]$} & 1.2 & 0.3 & 0.9 & 0.3 \\
\hline
\end{tabular}

\subsubsection{Boundary conditions}

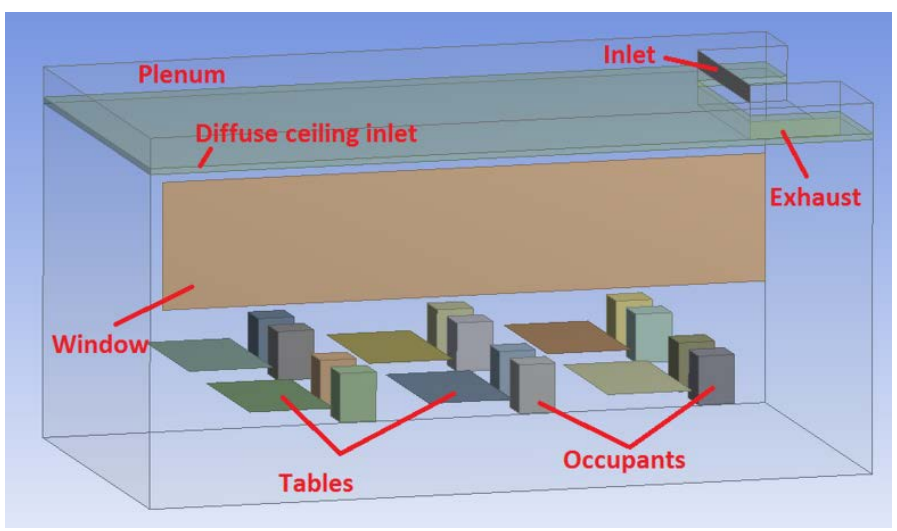

Figure 3: CFD model of the investigated room

The boundary conditions were used to define the situation from experimental setup in CFD. The inlet element situated on air handling unit was assigned with a uniform and constant velocity and temperature of the inlet air (see Table 5). 
Dimensions of inlet opening from air handling unit to plenum were $0.8 \mathrm{~m} \times 0.1 \mathrm{~m}$. Boundary on exhaust element was defined as static pressure outlet with dimensions of $0.45 \mathrm{~m} \times 0.10 \mathrm{~m}$. Occupants were modeled as blocks with floorplan dimensions of $0.25 \mathrm{~m} \times 0.20 \mathrm{~m}$ and height of $0.45 \mathrm{~m}$, (see Figure 3). Occupants were placed on horizontal plates with floor-plan dimensions of $0.45 \mathrm{~m} \times 0.40 \mathrm{~m}$, representing the chairs. The plates were situated at a height of $0.55 \mathrm{~m}$. The tables were modeled as horizontal plates with dimensions of $1.3 \mathrm{~m} \times 0.7 \mathrm{~m}$ placed at a height of $0.7 \mathrm{~m}$. The heat generated by lighting fixtures was released into the volume close to porous suspended ceiling. The surfaces boundary conditions were assigned with an external heat transfer coefficient $\left(0.33 \mathrm{~W} /\left(\mathrm{m}^{2} \cdot \mathrm{K}\right)\right.$ for roof, $0.36 \mathrm{~W} /\left(\mathrm{m}^{2} \cdot \mathrm{K}\right)$ for wall, $2.50 \mathrm{~W} /\left(\mathrm{m}^{2} \cdot \mathrm{K}\right)$ for floor and $0.8 \mathrm{~W} /\left(\mathrm{m}^{2} \cdot \mathrm{K}\right)$ for window).

\subsubsection{Porous zone model}

Porous zone model was used in CFD calculations to simulate the pressure drop across the porous suspended ceiling. The inputs were determined based on measured pressure drop. The porous suspended ceiling was modelled in Fluent as fluid domain with added momentum loss equation. The porosity was set as isotropic with a value of $15 \%$, according to known open area of perforated gypsum plate. The momentum loss was defined by viscous and inertial resistance coefficients, being $1.306 \times 10^{9} \mathrm{~m}^{-2}$ and $1,185,000 \mathrm{~m}^{-1}$, respectively. Those values were obtained from quadratic regression analysis of measured values of pressure drop and velocity expressed by Eq. (4)

$$
\Delta p=35554 \cdot v^{2}+1181.8 \cdot v \quad \text { Eq. (4) }
$$

Where: $\Delta p$ is measured pressure drop across the porous suspended ceiling and $v$ is velocity of the air flowing through porous suspended ceiling.

\subsubsection{Turbulence modeling}

The air in the room ventilated by use of diffuse ceiling inlet could often move due to natural convection, especially in close proximity to walls and heat sources. The Boussinesq model was used to calculate natural convection caused by buoyancy forces [21]. The buoyant model was defined by gravity-acceleration vertical component of $9.81 \mathrm{~m} / \mathrm{s}^{2}$. The transient approach was applied for our calculations with use of the Large Eddy Simulation method to model the turbulence effects. It was found that steady-state calculations investigating ventilation in the room had difficulties to converge and results of such calculations were not satisfactory to validate the CFD model. Some authors also stated 
that Large Eddy Simulation model gives more accurate results than models using steady-state approach, for investigations of air flow in the room [21].

\section{Results analysis and discussion}

\subsection{Indoor climate}

Table 2 shows results of PPD calculations. The highest values were obtained at heights close to the floor, as a result of combination of low temperatures and high velocities in this area. The average values of PPD were $6.0 \%$ and $7.3 \%$ for air change rate of $6.6 \mathrm{~h}^{-1}$ and $9.1 \mathrm{~h}^{-1}$ respectively. Scenario 1 was in category A and Scenario 2 was in category B concerning the PPD evaluation [14]. Even though that Scenario 1 was in category B and Scenario 2 in category A concerning the air change rates. The higher air change rates very often result in higher velocities in the room. Those are often accompanied with lower indoor temperatures since more heat is removed from the room.

Table 2: PPD results based on measurements

\begin{tabular}{ccccccc}
\hline & \multicolumn{3}{c}{ Scenario 1 } & \multicolumn{3}{c}{ Scenario 2 } \\
\hline $\begin{array}{c}\text { Height } \\
{[\mathrm{m}]}\end{array}$ & Stand 1 & $\begin{array}{c}\text { Stand 2 } \\
{[\%]}\end{array}$ & Stand 3 & Stand 1 & $\begin{array}{c}\text { Stand 2 } \\
{[\%]}\end{array}$ & Stand 3 \\
\hline 0.1 & 9.0 & 9.0 & 6.0 & 10.0 & 13.0 & 7.0 \\
0.6 & 5.0 & 6.0 & 5.0 & 6.0 & 7.0 & 6.0 \\
1.1 & 6.0 & 5.0 & 5.0 & 7.0 & 6.0 & 6.0 \\
1.7 & 6.0 & 5.0 & 5.0 & 7.0 & 6.0 & 6.0 \\
\hline
\end{tabular}

\subsection{Draught rating}

Table 3: Draught rating results based on measurements

\begin{tabular}{ccccccc}
\hline & \multicolumn{3}{c}{ Scenario 1 } & \multicolumn{3}{c}{ Scenario 2 } \\
\hline $\begin{array}{c}\text { Height } \\
{[\mathrm{m}]}\end{array}$ & Stand 1 & $\begin{array}{c}\text { Stand 2 } \\
{[\%]}\end{array}$ & Stand 3 & Stand 1 & $\begin{array}{c}\text { Stand 2 } \\
{[\%]}\end{array}$ & Stand 3 \\
\hline 0.1 & 0.0 & 4.8 & 0.0 & 0.0 & 8.9 & 3.0 \\
0.6 & 0.0 & 0.0 & 2.7 & 0.0 & 2.7 & 3.3 \\
1.1 & 0.0 & 0.0 & 4.4 & 0.0 & 0.0 & 5.8 \\
1.7 & 3.3 & 4.5 & 0.0 & 5.0 & 3.0 & 0.0 \\
\hline
\end{tabular}

As already mentioned in section 3.1, higher flow rates can contribute to decreased comfort of occupants. This is suggested also by draught rating results shown in Table 3. The draught ratings for different stand points in the room 
were kept rather low. The main reasons were generally low velocities of the air within the room. Highest draught rating value was $8.9 \%$ and average value was $1.6 \%$ and $2.6 \%$ for air change rates $6.6 \mathrm{~h}^{-1}$ and $9.1 \mathrm{~h}^{-1}$ respectively. Both scenarios were in indoor environmental category A concerning draught rating [14].

\subsection{Tracer-gas measurement}

The ventilation effectiveness was calculated for a period of one hour, based on the tracer-gas measurements. The results for both investigated scenarios are depicted on Figure 4. The averaged values for ventilation effectiveness were 0.81 and 0.87 for Scenario 1 and 2 respectively.
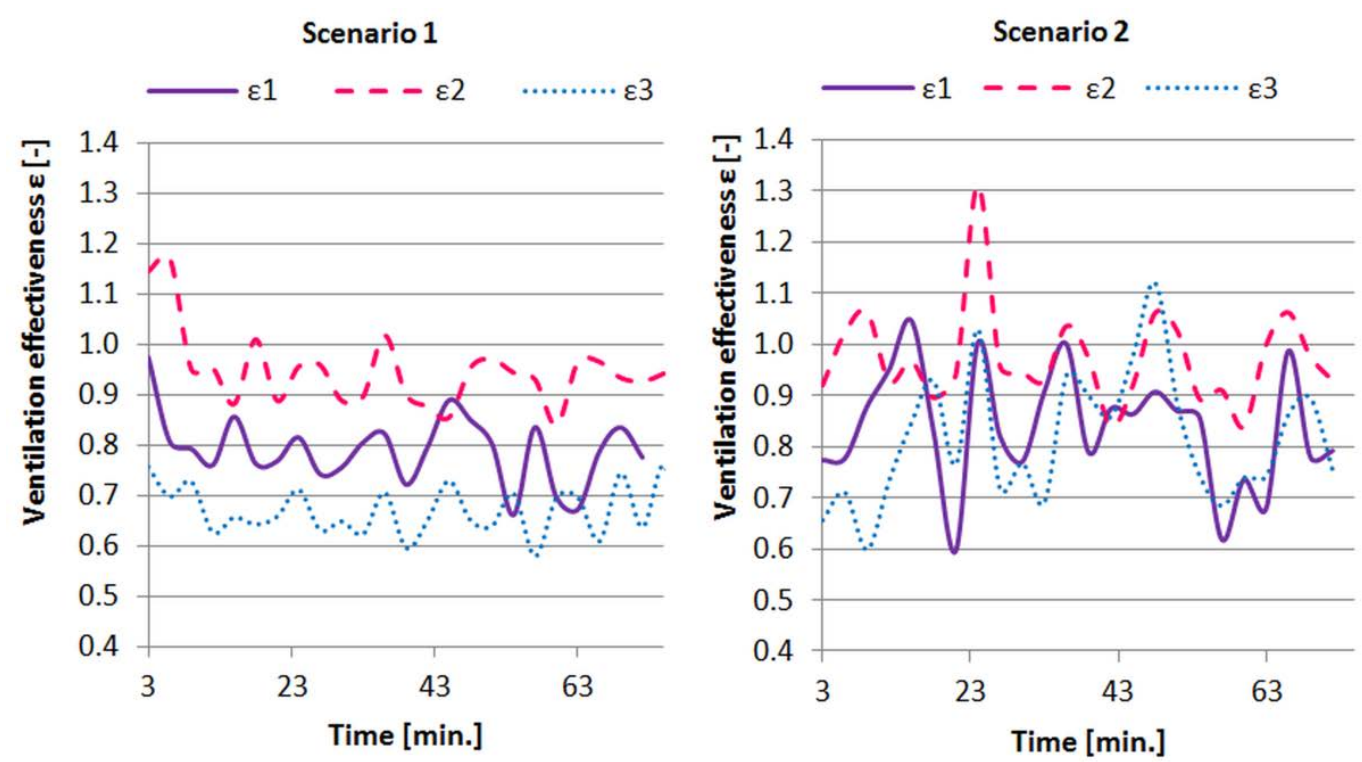

Figure 4: Ventilation effectiveness

The Local Mean Age of air analysis suggests that exhaust orientation influenced the airflow patterns, assuming that fresh air distribution from the porous suspended ceiling was uniform. The Local Mean Age of air at points 3 and 6 was higher than other points which can be attributed to the position of exhaust (see Figure 1). The results of all investigated points are shown in Table 4.

Table 4: Local Mean Age of air results

\begin{tabular}{|c|c|c|c|c|c|c|c|c|}
\hline \multirow[b]{2}{*}{ Point } & \multicolumn{7}{|c|}{ Local mean age of air (minutes) } & \multirow[b]{2}{*}{ Room mean age of air } \\
\hline & 1 & 2 & 3 & 4 & 5 & 6 & Exhaust & \\
\hline Scenario 1 & 11.52 & $\mathrm{~N} / \mathrm{A}$ & 11.10 & 9.89 & 10.02 & $\mathrm{~N} / \mathrm{A}$ & 10.61 & 10.63 \\
\hline Scenario 2 & 6.37 & 6.16 & 7.90 & 7.42 & 6.31 & 10.95 & 7.56 & 7.52 \\
\hline
\end{tabular}




\subsection{Temperatures}

The results of temperature measurements were taken for periods when the indoor temperature conditions were stabilized. The measured temperatures of the inlet air (from air handling unit to plenum) were $21.0^{\circ} \mathrm{C}$ and $20.9^{\circ} \mathrm{C}$ for air change rates $6.6 \mathrm{~h}^{-1}$ and $9.1 \mathrm{~h}^{-1}$ respectively. The measured and calculated exhaust air temperatures are shown in Table 5. The resulting cooling loads were $23 \mathrm{~W} / \mathrm{m}^{2}$ and $30 \mathrm{~W} / \mathrm{m}^{2}$ for Scenario 1 and 2 respectively.

Table 5: Temperatures of inlet and exhaust openings

\begin{tabular}{lccc}
\hline & & Scenario 1 & Scenario 2 \\
\hline Inlet & {$\left[{ }^{\circ} \mathrm{C}\right]$} & 21.0 & 20.9 \\
Exhaust measured & {$\left[{ }^{\circ} \mathrm{C}\right]$} & 24.7 & 24.3 \\
Exhaust calculated & {$\left[{ }^{\circ} \mathrm{C}\right]$} & 25.0 & 23.6 \\
\hline
\end{tabular}

When looking at the temperature development of the three investigated points (the locations of temperature measurement points are shown in Figure 1), one could notice that the highest temperatures were experienced at higher positions of sensors as can be seen on Figure 5. The most rapid change in temperature was found between height $0.1 \mathrm{~m}$ and $0.6 \mathrm{~m}$. Lower temperatures below the level of $0.6 \mathrm{~m}$ can be explained by supplying colder air into the room which is dropping down and spreading across the floor. This phenomenon was evaluated by use of draught rating values, since people are most sensitive to high velocities at height of ankles (see Table 3). On the contrary, smaller temperature increase was experienced between heights $0.9 \mathrm{~m}$ and $1.7 \mathrm{~m}$. This can be explained by interaction of heated room air with colder supply air entering the room through the perforated suspended ceiling. As it can be seen from Figure 5, the results from numerical calculations gave slightly higher values of room air temperatures for Scenario 1. Different situation was however for Scenario 2, depicted on Figure 6. In this scenario, the calculated temperatures were lower than measured values, see Table 6 for difference. The explanation for this situation could be the fact that fresh air was supplied to the room with higher velocity, therefore causing better mixing of the supply air and room air. The smaller vertical temperature difference in Scenario 2 compare to Scenario 1, for measured and also calculated values, further supports this assumption, see Table 7. Furthermore, the higher ventilation effectiveness for Scenario 2 found by tracer-gas measurements means that the air in the room is replaced faster with the supply air (which has lower temperature) and therefore resulting in lower temperatures in the room, (see section 3.3).

Table 6: Air room temperature difference between measured and CFD values

\section{$\Delta \mathrm{T}[\mathrm{K}]$}




\begin{tabular}{lccc} 
& Min. & Max. & Average \\
\hline Scenario 1 & 0.02 & 0.44 & 0.16 \\
Scenario 2 & 0.16 & 0.83 & 0.61 \\
\hline
\end{tabular}

Table 7: Vertical temperature differences

\begin{tabular}{|c|c|c|c|}
\hline \multicolumn{4}{|c|}{ Vertical temperature difference $[\mathrm{K}]$} \\
\hline \multicolumn{2}{|c|}{ Scenario 1} & \multicolumn{2}{|c|}{ Scenrio 2} \\
\hline Measured & CFD & Measured & CFD \\
\hline 0.62 & 0.76 & 0.43 & 0.37 \\
\hline
\end{tabular}

The difference between measured and calculated temperatures could also be attributed to uncertainty in determining heat transfer coefficients of building facades. The test room was placed outdoor and therefore its thermal behavior was subject to variations of the outdoor environment. The external part of the heat transfer coefficient is influenced by wind conditions and sky temperature - neither of those values was taken into account during experiment. The internal part of the heat transfer coefficient of building facades was influenced by the flow pattern in the room in proximity to the wall surfaces. This can also influence the heat loss through the constructions. As there was a large temperature difference between the indoor air and the outside environment $(23-25 \mathrm{~K})$, slight variation of heat transfer coefficient of building facades would result in a noticeable disagreement in temperature prediction of the indoor air.

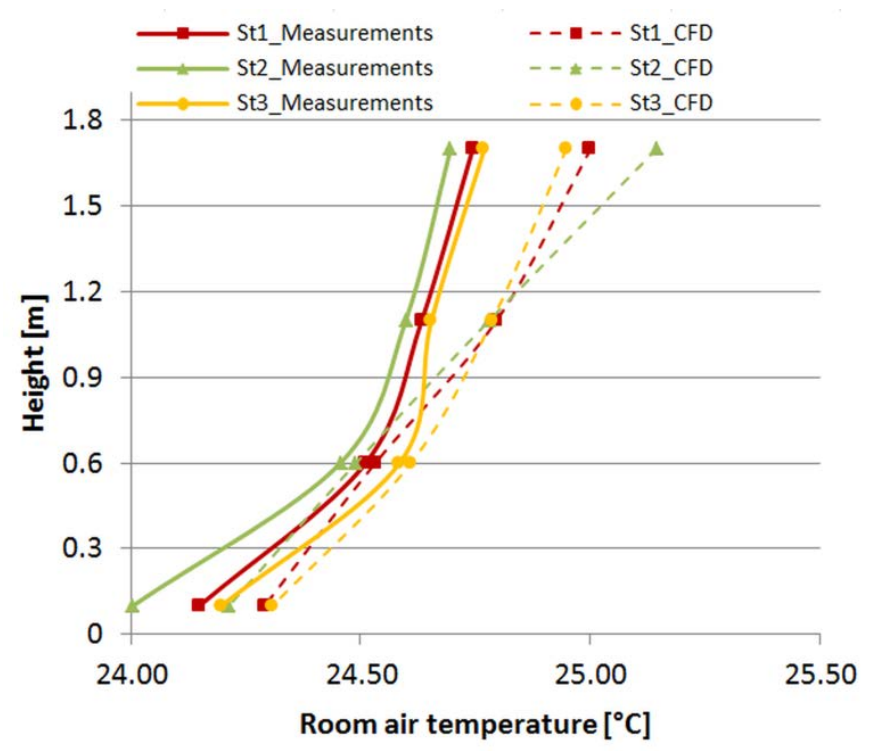

Figure 5: Measured and calculated temperatures in investigated points for Scenario 1 


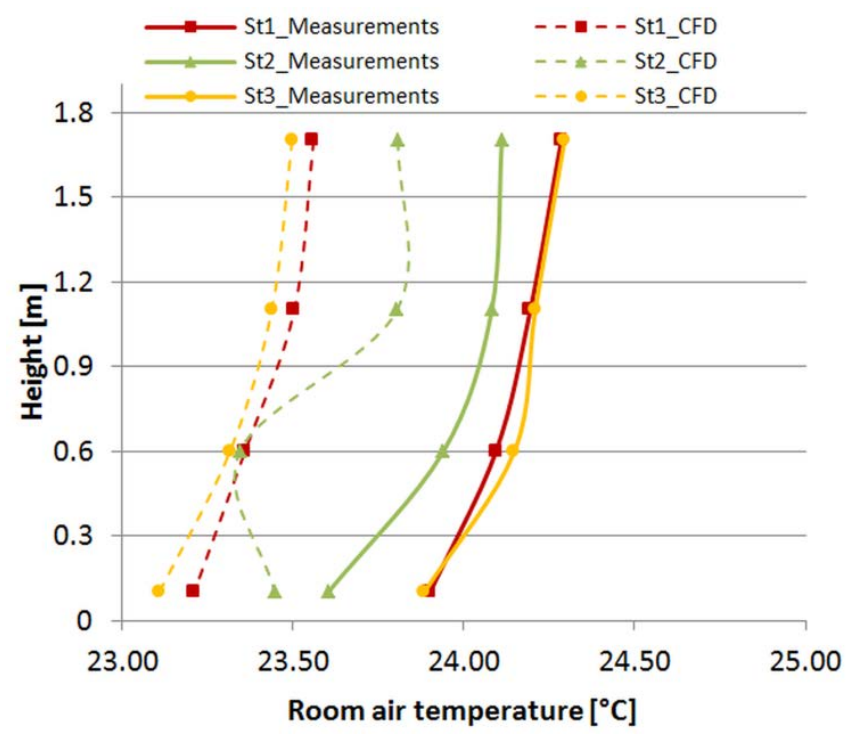

Figure 6: Measured and calculated temperatures in investigated points for Scenario 2

Figure 7 shows the result of the room air temperature distribution of Scenario 1 from CFD calculations (the position of longitudinal, vertical plane where results are taken is shown on Figure 1). The thermal plums were created above the occupants being the heat sources. Those thermal plums were rising up to the ceiling and could possibly restrict the air flow at areas above the occupants. Situation in Figure 7 suggests that the supply air was entering the room mainly in areas between the occupants and in the area of the room further away from the air handling unit. The higher amount of supplied air at the end of the room can be explained by luck of heat sources in this area. Furthermore, the inlet air was supplied from air handling unit into the plenum with certain momentum which could cause a higher pressure gradient in the area of plenum further away from the air handling unit, resulting in larger amounts of fresh air entering the room in that area.

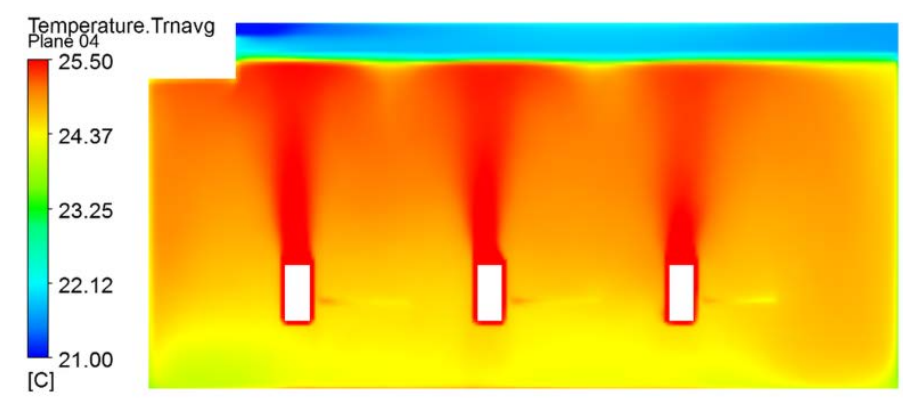

Figure 7: Temperature distribution of Scenario 1 from CFD 


\subsection{Velocities}

Figure 8 shows the velocities in the room and plenum from CFD calculations. Higher air velocities in the room were experienced in area situated further away from the air handling unit. This can also be problematic area concerning the thermal comfort since the cold air is falling down resulting in higher velocity close to the floor surface. The results of air velocity measurements and calculations for two different scenarios are depicted on Figures 9-10. The locations of velocity measurement points are shown in Figure 1. The showed values were calculated as average of 10 minutes measurements taken every 10 seconds. The velocities were generally low throughout the room, considering rather high ventilation flow rates used during our investigations. There were differences between measured and calculated velocities, mostly in areas close to the floor. The possible cause for those differences was the lower level of mixing in CFD calculations compared to measurements, which can be explained by approximate interpretation of perforated suspended ceiling in the CFD model (as explained in section 2.2.3). The porous zone ensured that proper pressure drop was applied for air flowing from the plenum to the room, however it did not ensure the same air velocity just below the porous suspended ceiling. Since the whole area of suspended ceiling was used as supply area in CFD, while the supply area was only $15 \%$ of the suspended ceiling area in measurements. This approximation inevitably results in lower air velocity just below the porous suspended ceiling in CFD calculations. Also larger vertical temperature difference depicted on Figure 5 supports the opinion about lower level of mixing in CFD calculations. The air movement around and above the occupants was increased dramatically as a result of generated heat, as can be seen on Figure 8. It was very challenging to get some consistent patterns concerning velocity development in the room when large fluctuations occurred. This is the reason why we used transient calculations which took into account the fluctuation of the air flow by averaging the values in different time steps. In conclusion, the CFD models are considered to be reliable.

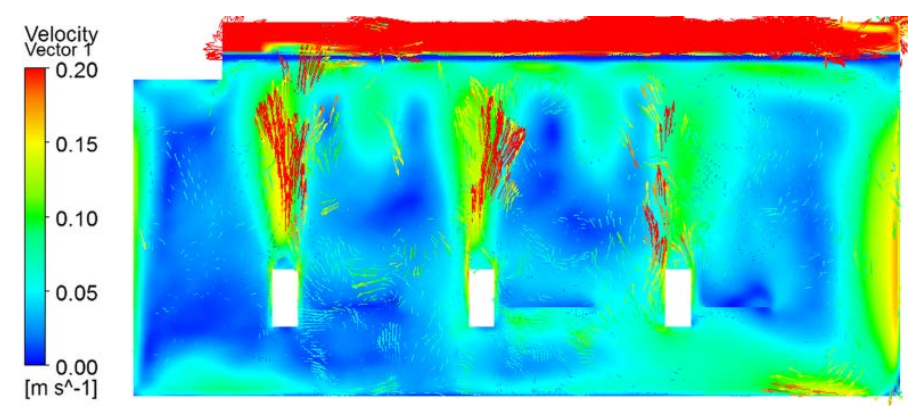

Figure 8: Velocity distribution of Scenario 1 from CFD 


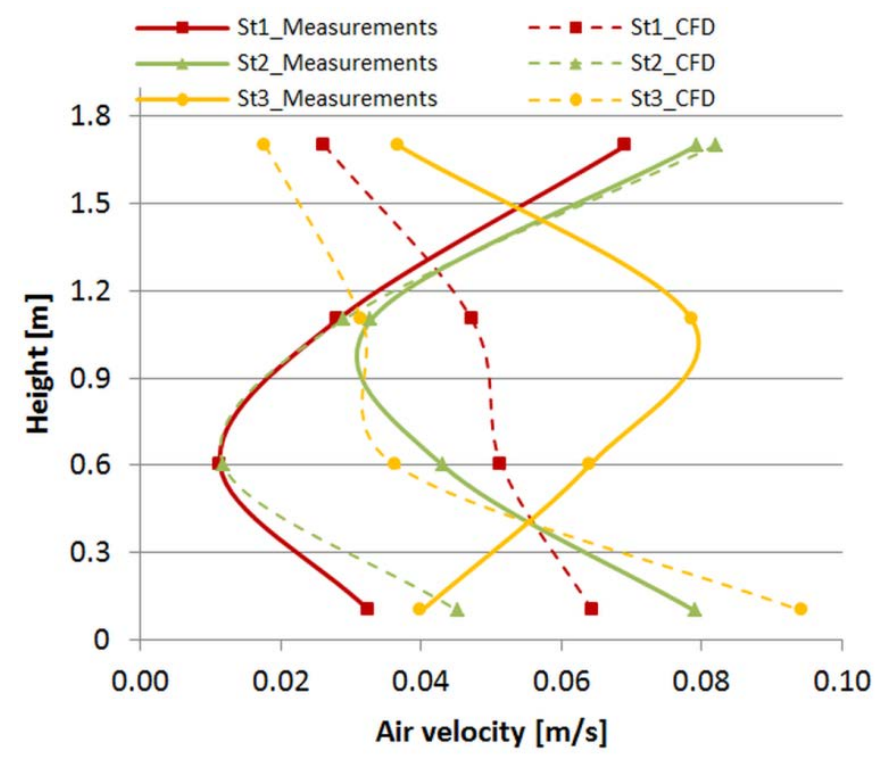

Figure 9: Measured and calculated velocities in investigated points for Scenario 1

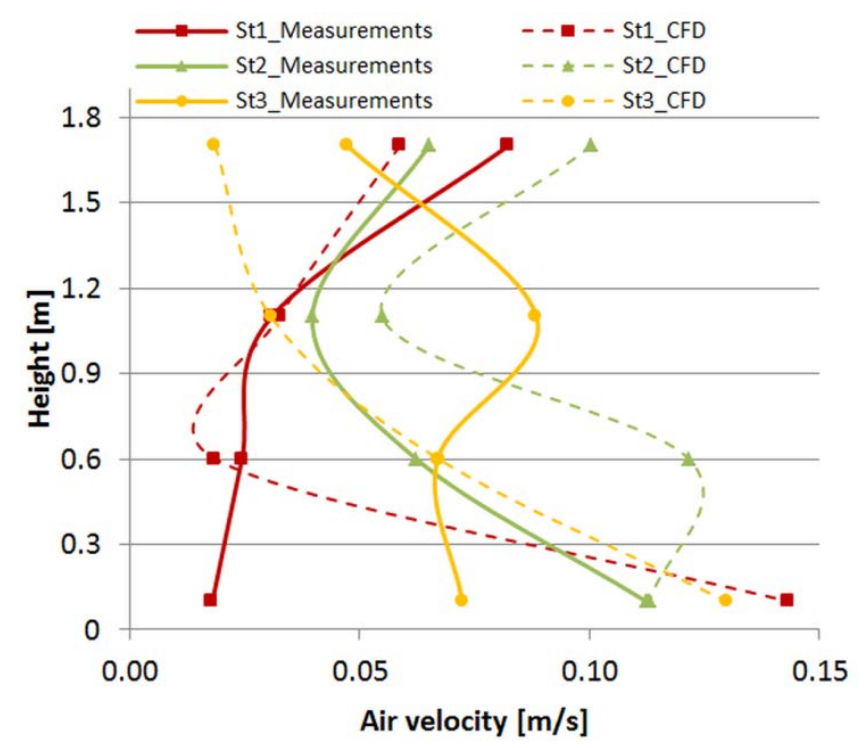

Figure 10: Measured and calculated velocities in investigated points for Scenario 2

3.6 Airtightness of gypsum connections and pressure drop across diffuse ceiling inlet

Figure 11 shows the picture taken by thermo-graphic camera [23] during our investigations to validate the assumption that the connections between gypsum boards were air tight. The green line on the Figure 11 shows place of connection of the two neighboring gypsum plates. Increased air flow was not experienced in that area. On the 
contrary, the air flow was decreased as a result of application of silicone paste in and around connections of gypsum boards. The measured pressure drop across the diffuse ceiling inlet was $7.2 \mathrm{~Pa}$ for Scenario 1 and $10.16 \mathrm{~Pa}$ for Scenario 2.

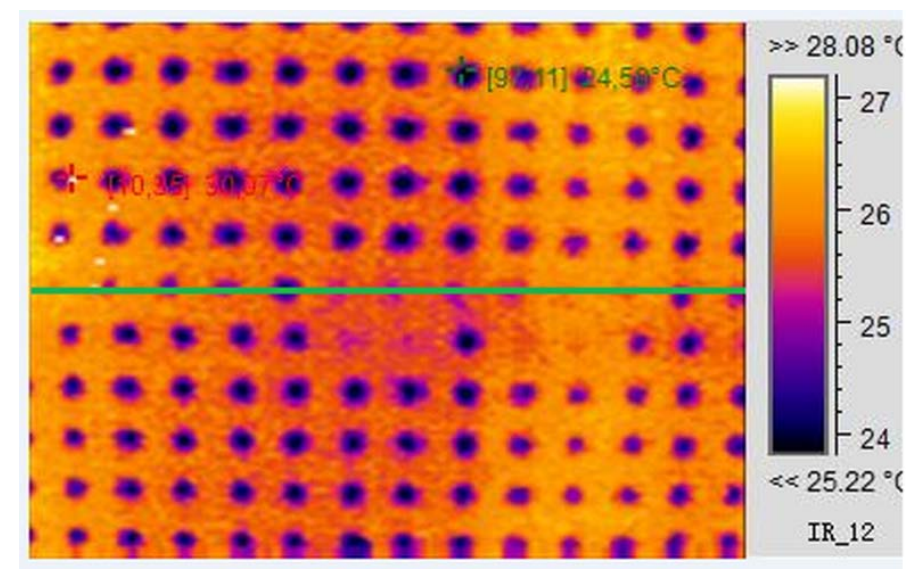

Figure 11: Thermo-graphic picture of gypsum connection

\subsection{Parametrical study results}

In order to investigate the influence of different suspended ceiling setup on indoor climate, the scenario with reduced ceiling inlet area was studied in CFD, see Figure 12. It consisted of three rectangles (green color) situated at positions above the tables. Each supply rectangle had dimensions of $3.15 \mathrm{~m} \times 0.70 \mathrm{~m}$, resulting in overall area of $6.60 \mathrm{~m}^{2}$ (compare to original supply area of $18.60 \mathrm{~m}^{2}$ ). The rest of the area of suspended ceiling was assumed to be solid, so the air could not penetrate through it.

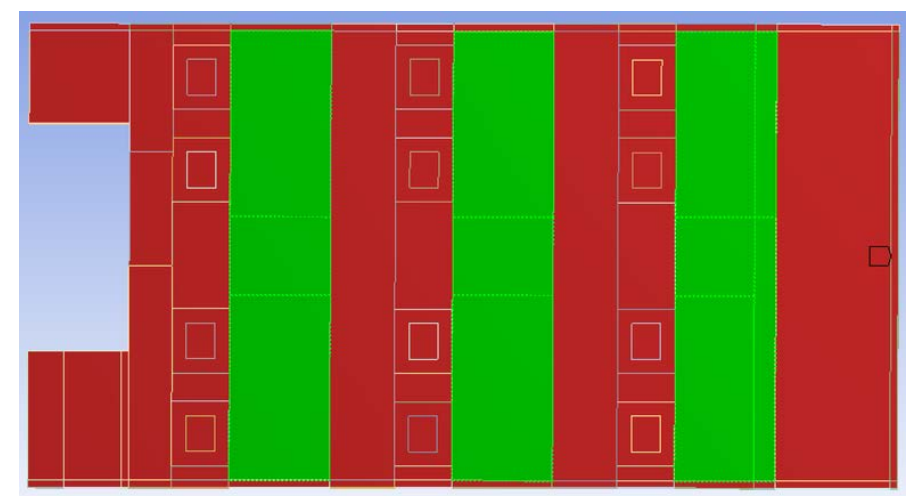

Figure 12: Parametrical study-reduced area of supply opening

As it can be seen from Figure 13, the temperatures in the case of reduced supply area of suspended ceiling were generally low. This can be explained by different flow pattern in the room compare to the situation where the whole 
area of suspended ceiling was activated as a supply diffuser. The flow pattern has an influence on velocity and temperature development in the room and also on the heat loss through the building facades. As can be seen on Figure 14, the velocities were higher in the case with reduced supply area. This resulted in higher convective heat transfer coefficient of the room surfaces, leading to higher heat losses and resulting in lower temperatures in the room. The heat loss through the room surfaces was $641 \mathrm{~W}$ in alternative with reduced supply area, whereas it was 580 W in case with whole area of suspended ceiling activated as a supply diffuser. The heat loss by ventilation was $371 \mathrm{~W}$ for the case of reduced supply area and $432 \mathrm{~W}$ for the case of whole area of suspended ceiling activated as a supply diffuser. On Figure 13 it can be seen that vertical temperature difference was smaller in the case of reduced supply area of suspended ceiling, which further lowers the ventilation heat loss, since exhaust opening was situated in proximity of suspended ceiling. It also means that the air is better mixed in the case of reduced supply area of suspended ceiling.

The validated CFD model can be used in further parametrical studies with focus on investigation of indoor climate in different scenarios with various boundary conditions.

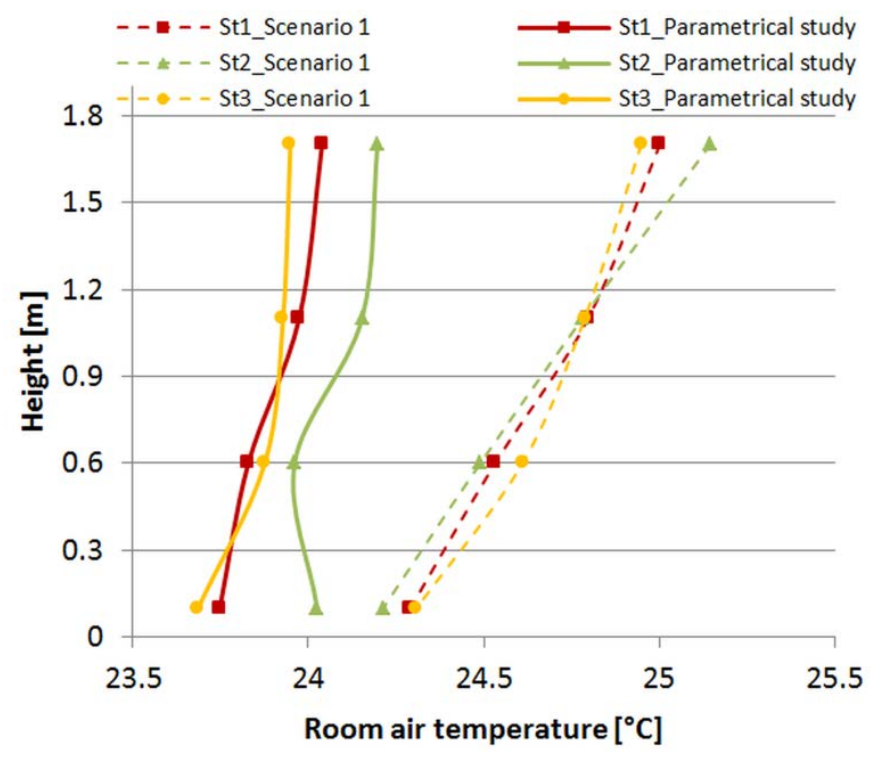

Figure 13: Comparison of temperatures from two different CFD calculations 


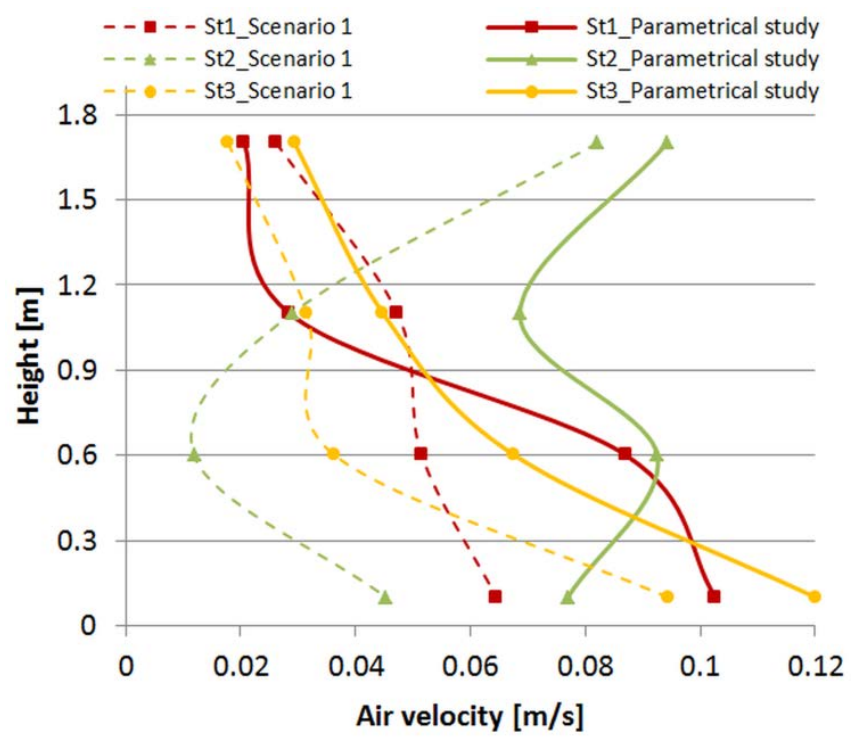

Figure 14: Comparison of velocities from two different CFD calculations

\section{Conclusion}

Experimental and numerical investigations were carried out in real test room placed in an outdoor environment. Results of our investigations have shown that diffuse ceiling inlet is a suitable solution for the spaces with high density occupancy. The diffuse ceiling inlet can therefore be considered as well performing alternative to the traditional means of mechanical ventilation for air change rate of $6.6 \mathrm{~h}^{-1}-9.1 \mathrm{~h}^{-1}$. The room was cooled by outside air by $23-30$ $\mathrm{W} / \mathrm{m}^{2}$ without draught problem due to high speed of air and low temperature. The velocities of air in the room were reasonably low throughout the whole investigated space. The special attention should be paid to areas close to the floor, where highest velocities were experienced in measured and also calculated results. The tracer-gas investigations have shown that the air in the room is mixed with average ventilation effectiveness of $84 \%$. The authors recommend the use of transient equations for CFD investigations of air flow in the room.

\section{Acknowledgement}

This research came to existence thanks to kind sponsorship of companies Airmaster ${ }^{\bullet}$, Knauf Danoline ${ }^{\bullet}$, and Connovate $\mathrm{A} / \mathrm{S}$. We were able to do thorough numerical investigations thanks to the high performance computing platform kindly provided by Beijing Computing Center. 


\section{References}

[1] EPDB, Energy Performance of Building Directive, European Union, http://europa.eu/ legislation_summaries/ other/I27042_en.htm

[2] LOMBARD, P., L., ORTIZ, J., POUTCH, A review on buildings consumption information, Energy and Buildings 40 (2008). pp. 394-398.

[3] Shaughnessy, R. J., Haverinen-Shaughnessy U., Nevalainen A., Moschandreas D., 2006. A preliminary study on the association between ventilation rates in classrooms and student performance. Indoor Air, 16, 465-468.

[4] Seppanen O.A., Fisk W.J., Mendell M.J., Association of Ventilation Rates and CO2 Concentrations with Health and Other Responses in Commercial and Institutional Buildings, Indoor Air 1999;9:226-252;, ISSN 0905-6947

[5] Wyon, D. P., 2004. The effects of indoor air quality on performance and productivity. Indoor Air, 14 (Suppl. 7), 92101.

[6] Wargocki, P., Wyon, D. P., 2013. Providing better thermal and air quality conditions in school classrooms would be cost-effective. Building and Environment, 59, 581-589.

[7] Hviid ${ }^{a, b}$ Ch.A., Svendsen ${ }^{b}$ S., Experimental and numerical analysis of perforated suspended ceilings as diffuse ventilation air inlets, Energy and Buildings 56(2013) 160-168

[8] Hviid Ch.A., Terkildsen S., Experimental study of diffuse ceiling ventilation in a classroom, Technical University of Denmark, Corresponding author: sterk@byg.dtu.dk

[9] Jacobsen L., Air Motion and Thermal Environment in Pig Housing Facilities with Diffuse Inlet, Aalborg University Department of Civil EngineeringArchitectural Engineering, December 2006, Phd thesis

[10] Jensen, J. L., Experimental and numerical analysis of the cooling potential with diffuse ceiling ventilation. Thesis (MSc). Technical University of Denmark, 2012

[11] Yang H.., Experimental and numerical analysis of diffuse ceiling ventilation, M.Sc. thesis, Department of Civil Engineering, Technical University of Denmark, (2011)

[12] Nielsen ${ }^{1}$ P.V., Jakubowska ${ }^{2}$ E., The Performance of Diffuse Ceiling Inlet and other Room Air Distribution Systems, Corresponding email: pvn@civil.aau.dk 
[13] Information provided by Erik Bjørn, Ph.D, who is R\&D Manager in company Airmaster A/S producing ventilation unit, www.airmaster.dk

[14] European Committee for Standardization, 2007. EN 15251:2007. Indoor environmental input parameters for design and assessment of buildings addressing indoor air quality, thermal environment, lighting and acoustics.

[15] International Organization for Standardization, 2005. EN ISO 7730:2005. Ergonomics of the thermal environment: Analytical determination and interpretation of thermal comfort using calculation of the PMV and PPD indices and local thermal comfort criteria.

[16] Heller, A., 2000. Large-Scale Solar Heating - Evaluation, Modelling and Designing. Thesis (PhD). Technical University of Denmark.

[17] http://www.onsetcomp.com/products/data-loggers/u12-012

[18] http://www.sensor-electronic.pl/pdf/KAT_AirDistSys5000.pdf $\left[\right.$ [Last accessed: 19 ${ }^{\text {th }}$ April 2014].

[19] http://www.lumasenseinc.com/L[Last accessed: $19^{\text {th }}$ April 2014].

[20] Han H., Ventilation Effectiveness Measurements Using Tracer Gas Technique, Fluid Dynamics, Computational Modeling and Applications, 2012, Dr. L. Hector Juarez (Ed.), ISBN: 978-953-51-0052-2, InTech.

[21] http://ansys.com/Products/Simulation+Technology/Fluid+Dynamics/Fluid+Dynamics+Products/ANSYS+Fluent 2 [Last accessed: $19^{\text {th }}$ April 2014].

[22] Nielsen P., Allard F., Awbi H., Davidson L., Schalin A., Computational Fluid Dynamics in Ventilation Design, Rehva Guidebook no.10, 2007, page 48

[23] SDS-Infrared ${ }^{\circ}$. Hot-Find D. [Online.] Available from: http://www.emtamericas.com/pdf/Satir_Hotfind.pdf [Last accessed: $19^{\text {th }}$ April 2014]. 